\title{
KẾT QUẢ ĐIỀU TRI VIÊM PHÚC MẠC RUộT THỪA BẰNG PHẪU THUÂT NộI SOI TẠI MộT SỐ BỆNH VIỆN ĐA KHOA TỈNH MIỀN NÚI PHÍA BẮC
}

\begin{abstract}
TÓM TẮT
Mục tiêu: Nghiên cứu điều trị viêm phúc mac ruột thừa bằng phẫu thuật nội soi (PTNS) tại một số bệnh viện đa khoa tỉnh miền núi phía Bắc. Đối tượng và phương pháp: Tiến cứu mô tả tiến hành trên 468 bệnh nhân được chẩn đoán VPMRT được điều trị bằng phẫu thuật nội soi từ 01/01/2015 đến 31/9/2017 tại các bệnh viện đa khoa tỉnh miền núi phía Bắc. Kểt quả và kết luận: Tỉ lệ thành công của phẫu thuật nội soi là 97,6\%; nguyên nhân chuyển mổ mở đa phẩn do không có khá năng xử lý tổn thương; đa số bệnh nhân được đặt 3 trocar; hâuu hết bệnh nhân được đặt trocar ở rốn + mạng sườn phải + hố chậu trái; áp lực bơm hở ổ bụng đa phân là $11-12 \mathrm{mmHg}$; chẩn đoán trong mổ đa số là VPMRT toàn thể chiếm $76,7 \%$; đa số bệnh nhân được cắt RT xuôi dòng; thời gian phẩu thuật nội soi đa số nằm trong khoảng 31-60 phút; có 2 bệnh nhân gặp tai biến trong mổ và 8 bệnh nhân gặp biến chứng sớm sau mổ; thời gian nằm viện sau mổ đa số 6-7 ngày chiếm 49,5\%.
\end{abstract}

Ti̛ khóa: Viêm phúc mạc ruột thừa (VPMRT), phẫu thuật nội soi (PTNS)

\section{SUMMARY \\ TREATMENT OF APPENDICEAL PERITONITIS BY LAPAROSCOPIC SURGERY IN NORTHERN MOUNTAINOUS HOSPITALS}

Objective: To study the treatment of appendiceal peritonitis (AP) by laparoscopic surgery (LS) at some Northern mountainous general hospitals. Subjects and methods: Prospective descriptive study conducted on 468 patients diagnosed with AP treated by LS from January 1, 2015 to September 31, 2017 at northern mountainous general hospitals. Results and conclusion: The success rate of laparoscopic surgery was $97.6 \%$; The reason for conversion to open surgery is mostly due to the inability to handle the injury; the majority of patients were placed 3 trocars; most patients have trocar placed in umbilicus + right ribs + left iliac fossa; The most common intraabdominal inflation pressure is $11-12 \mathrm{mmHg}$; The majority of diagnoses in surgery are generalized peritonitis, accounting for $76.7 \%$; the majority of patients hadcutting appendix by downstream method; laparoscopic surgery time is mostly in the range of 3160 minutes; 2 patients had complications during surgery and 8 patients had early complications after surgery; The majority of time stay in hospital after

*Bệnh viện Đa khoa Chiêm Hóa

**Bêenh viên Hữu Nghi Viêtt Đức

Chịu trách nhiệm chính: Nguyễn Hưng Đạo

Email: bienpham1102@gmail.com

Ngày nhận bài: $11 / 7 / 2021$

Ngày phản biên khoa học: 9/8/2021

Ngày duyệt bài: 25/8/2021

\section{Nguyễn Hưng Đạo*, Trịnh Hồng Sơn**}

surgery is 6-7 days, accounting for $49.5 \%$.

Keywords: Appendicitis peritonitis (AP), laparoscopic surgery (LS)

\section{I. ĐĂT VẤN ĐỀ}

Viêm ruột thừa (VRT) là một trong những cấp cứu ngoại khoa gặp hàng đầu. Viêm phúc mạc (VPM) do viêm ruột thừa (VRT) là một biến chứng nặng hay gặp trong thực hành lâm sàng. Việc phẫu thuật và điều trị bênh nhân viêm phúc mạc ruột thừa (VPMRT) sẽ tốn kém, khó khăn và để lại nhiều di chứng so với giai đoạn sớm. Phẫu thuật nội soi là phương pháp điều trị VRT cũng như VPMRT hiệu quả và an toàn. Tại các tỉnh miền núi phía Bắc chưa có một nghiên cứu nào một cách hệ thống về nguyên nhân và điều trị VPMRT bằng PTNS, để góp phần có được một kết luận khoa học, làm căn cứ cho những can thiệp tiếp theo làm giảm tỷ lệ VPMRT và thống nhẩt hoàn thiện kỹ thuật phẫu thuật nội soi điều trị VPMRT tại đây, chúng tôi thực hiện nghiên cứu này.

\section{II. ĐỐI TƯợNG VÀ PHƯƠNG PHÁP NGHIÊN CỨU}

2.1. Đối tượng nghiên cứu. Tất cả các bệnh nhân được chẩn đoán VPMRT (VFMTT, VFMKT, Áp xe RT) được điều trị bằng phẩu thuất nội soi từ $01 / 01 / 2015$ đến $31 / 9 / 2017$ tại các bệnh viện đa khoa tỉnh miền núi phía Bắc.

\section{a. Tiêu chuẩn chon bênh nhân.}

- Gồm tất cả các bệnh nhân được chẩn đoán là VPM do VRT, các bệnh nhân này có triệu chứng lâm sàng và cận lâm sàng của một VRT có biến chứng VPM được điều trị bằng PTNS tại 8 bệnh viện đa khoa tuyến tỉnh là: Bắc Giang, Bắc Kạn, Cao Bằng, Điện Biên, Hà Giang, Hòa Bình, Sơn La, Tuyên Quang.

- Các bệnh nhân này có chẩn đoán trong mổ và sau mổ đều là VPM do VRT.

- Những bệnh nhân này có hồ sơ đầy đủ các dữ liệu chẩn đoán trước mổ, cách thức phẫu thuật, kết quả theo dõi và đánh giá kết quả sau mổ.

- Không có tiền sử mổ cũ từ hai lần trở lên hoặc bệnh nhân có đường mổ cả đường trắng giữa trên và dưới rốn

- Không có chống chỉ định trong phẫu thuật nội soi.

- Sau khi đã giải thích cho bệnh nhân hay người đại diện bệnh nhân về lợi ích và nguy cơ của phương pháp phẫu thuật nội soi, được họ 
đồng ý để tiến hành nghiên cứu.

b. Tiêu chuẩn loại trừ

- Không Không ghi chép đầy đủ các mục trong bệnh án mẫu nghiên cứu.

- Đám quánh ruột thừa

- Chẩn đoán sau mổ là VPM do các nguyên nhân khác.

\subsection{Phương pháp nghiên cứu}

a. Thiết kế nghiên cứu. Nghiên cứu mô tả, tiến cứu. Bệnh nhân được phẫu thuật theo một quy trình kỹ thuật thống nhất do các phẫu thuật viên của 8 bệnh viện đa khoa tuyến tỉnh là Bắc Giang, Bắc Kạn, Cao Bằng, Điện Biên, Hà Giang, Hòa Bình, Sơn La, Tuyên Quang thực hiện.

b. Các chỉ tiêu nghiên cứu. Bệnh nhân được ghi nhận trong bệnh án từ khi vào viện cho đến khi ra viện theo cùng một mẫu bệnh án nghiên cứu. Khám lại sau 3 tháng thông qua khám trực tiếp hoăc qua điện thoại.

- Phẩn loại chẩn đoán trong và sau mổ:

+ VFMRT toàn thể: Khi RT võ, mủ và dịch ruột, phân lan tràn khắp khoang bụng cả trên và dưới.

+ VPMRT khu trú:Khi RT võ được các quai ruột, mạc nối lớn, phúc mạc bao bọc xung quanh, mủ và dịch phân chỉ có tại một vùng nào đó trong khoang bụng.

+ Áp xe RT: Áp xe RT là một dạng VPM khu trú, ở trong là mủ và phân, bao bọc xung quanh là mạc nối lớn, ruột non, đại tràng và phúc mạc.

- Đánh giá kết quả phẫu thuật nội soi viêm phúc mạc ruột thừa:

+ Tỉ lệ thành công của PTNS

+ Nguyên nhân chuyển mổ mở

+ Chẩn đoán trong mổ

+ Đặc điểm PTNS: số lượng và vị trí đặt trocar, áp lực bơm hơi ổ bụng, kĩ thuật cắt ruột thừa, thời gian phẫu thuật, tai biến trong mổ, biến chứng sớm sau mổ, thời gian nằm viện

c. Thu thập thông tin và xử lý số liệu.

Thu thập thông tin. Tất cả các bệnh nhân được thu thập thông tin theo mẫu bệnh án thống nhất gồm toàn bộ các chỉ tiêu nghiên cứu nêu trên. Việc thu thập thông tin do trực tiếp các phẫu thuật viên tham gia phẫu thuật tại 8 Bênh viện đa khoa tỉnh miền núi: Bắc Giang, Bắc Kạn, Cao Bằng, Điện Biên, Hà Giang, Hòa Bình, Sơn La, Tuyên Quang.

Phương pháp xử lý số liệu. Các số liệu được xử lý trên máy vi tính bằng phần mềm SPSS 18.

d. Đạo đức nghiên cứu. Nghiên cứu được tiến hành đồng thuận của Hội đồng đạo đức Viện Nghiên cứu 108.

\section{KẾT QUẢ NGHIÊN CỨU}

- Tỉ lệ thành công của phẫu thuật nội

soi: Thành công: $97,6 \%$; Chuyển mổ mở: $2,4 \%$

Bảng 1. Nguyên nhân chuyển mổ mở

\begin{tabular}{|c|c|c|}
\hline Nguyên nhân & $\begin{array}{c}\text { Số bệ̂nh } \\
\text { nhẩn }\end{array}$ & $\begin{array}{l}\text { Tỷ lệ } \\
\text { \% }\end{array}$ \\
\hline $\begin{array}{c}\text { Tốn thương ruột trong phâu } \\
\text { thuật }\end{array}$ & 1 & 0,2 \\
\hline Không khâu buộc được gốc RT & 1 & 0,2 \\
\hline $\begin{array}{c}\text { Không có khả năng làm sạch } \\
\text { ổ bụng sau khi cắt RT }\end{array}$ & 2 & 0,4 \\
\hline $\begin{array}{l}\text { Bóc tách RT khỏi mạc treo } \\
\text { khó khăn }\end{array}$ & 1 & 0,2 \\
\hline $\begin{array}{c}\text { Không có khả năng xử trí nội } \\
\text { soi }\end{array}$ & 6 & 1,3 \\
\hline $\begin{array}{c}\text { Tống } \\
\end{array}$ & 11 & 2,4 \\
\hline
\end{tabular}

Bảng 2. Số lượng trocart

\begin{tabular}{|c|c|c|}
\hline Số trocart & $\begin{array}{c}\text { Số bệ̂h nhân } \\
(\mathbf{n = 4 5 7 )}\end{array}$ & Tỉ lệ $\mathbf{~ ( \% ) ~}$ \\
\hline 3 trocart & 453 & 99,1 \\
\hline 4 trocart & 4 & 0,9 \\
\hline
\end{tabular}

Bảng 3. Vị trí đặt trocart

\begin{tabular}{|c|c|c|}
\hline Vị trí & $\begin{array}{c}\text { Số bệnh } \\
\text { nhân(n=457) }\end{array}$ & $\begin{array}{c}\text { Tỉ lệ } \\
\mathbf{( \% )}\end{array}$ \\
\hline Hạ vị + HCT + Rốn & 92 & 20,1 \\
\hline $\begin{array}{c}\text { HCP + Hạ vị + HCT } \\
\text { + Rốn }\end{array}$ & 2 & 0,4 \\
\hline HCT + Rốn + HCP & 79 & 17,3 \\
\hline Rốn + HCP + Hạ vị & 1 & 0,2 \\
\hline Rốn + MSP + Hạ vị & 82 & 17,9 \\
\hline Rốn + MSP + HCT & 199 & 43,5 \\
\hline $\begin{array}{c}\text { Thượng vị + Rốn + } \\
\text { MSP + HCT }\end{array}$ & 2 & 0,4 \\
\hline
\end{tabular}

Bảng 4. Áp lực bớm hơi ố bung

\begin{tabular}{|c|c|c|}
\hline Áp lực & $\begin{array}{c}\text { Số bệnh nhân } \\
(\mathbf{n = 4 5 7 )}\end{array}$ & Tỉ lệ (\%) \\
\hline $8-10 \mathrm{mmHg}$ & 128 & 28,0 \\
\hline $11-12 \mathrm{mmHg}$ & 329 & 72,0 \\
\hline
\end{tabular}

Bảng 5. Chẩn đoán trong mố

\begin{tabular}{|c|c|c|c|}
\hline \multicolumn{2}{|c|}{ Chẩn đoán } & \multirow{2}{*}{$\begin{array}{c}\begin{array}{c}\text { Số bênh } \\
\text { nhẩn } \\
\text { (n=468) }\end{array} \\
236\end{array}$} & \multirow{2}{*}{ 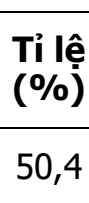 } \\
\hline \multirow{3}{*}{$\begin{array}{l}\text { Trước } \\
\text { phẫu } \\
\text { thuật }\end{array}$} & $\begin{array}{l}\text { VPMRT/ Ap xe } \\
\text { RT/ VPM }\end{array}$ & & \\
\hline & VRT & 231 & 49,4 \\
\hline & Tắc ruột CRNN & 1 & 0,2 \\
\hline \multirow{3}{*}{$\begin{array}{l}\text { Trong } \\
\text { phẫu } \\
\text { thuật }\end{array}$} & VPMRT toàn thế & 359 & 76,7 \\
\hline & VPMRT khu trú & 102 & 21,8 \\
\hline & Ap xe RT & 7 & 1,5 \\
\hline $\begin{array}{l}\text { Độ chính } \\
\text { xác }\end{array}$ & \multicolumn{3}{|c|}{$50,4 \%$} \\
\hline
\end{tabular}

- Kĩ thuật cắt ruột thừa: Xuôi dòng:: 96,9\%;

Ngược dòng: $3,1 \%$

Bảng 6. Thời gian phẫu thuật nội soi 


\begin{tabular}{|c|c|c|}
\hline Thời gian (phút) & $\begin{array}{c}\text { Số beệnh nhân } \\
(n=457)\end{array}$ & $\begin{array}{l}\text { Tỉ lệ } \\
(\%)\end{array}$ \\
\hline$\leq 30$ & $\frac{(n=45)}{66}$ & 14,4 \\
\hline $31-60$ & 296 & 64,8 \\
\hline $61-90$ & 85 & 18,6 \\
\hline \multirow{2}{*}{$\frac{91-120}{>120}$} & $\frac{0 J}{9}$ & 2,0 \\
\hline & & 0,2 \\
\hline $\begin{array}{c}\text { Trung bình } \pm \text { SD } \\
(\text { min-max })\end{array}$ & \multicolumn{2}{|c|}{$\begin{array}{c}50,35 \pm 17,87 \\
(17-155)\end{array}$} \\
\hline Tống & \begin{tabular}{l|l|} 
& 457 \\
\end{tabular} & 100,0 \\
\hline \multicolumn{3}{|c|}{ Bảng 7. Tai biến trong mố } \\
\hline Tai biến & $\begin{array}{c}\text { Số bệ̂nh nhân } \\
(n=457)\end{array}$ & $\begin{array}{l}\text { Tỉ lề } \\
(\%)\end{array}$ \\
\hline $\begin{array}{c}\text { Chảy máu sau phâu } \\
\text { thuật }\end{array}$ & $(3-4)$ & 0,2 \\
\hline \multirow{2}{*}{ Tốn thương ruột non } & 1 & 0,2 \\
\hline & 2 & 0,4 \\
\hline \multicolumn{3}{|c|}{ Bảng 8. Biến chứng sớm sau mổ } \\
\hline Biến chứng & $\begin{array}{c}\text { Số bệnh nhân } \\
(n=468)\end{array}$ & $\begin{array}{l}\text { Tỷ lệ } \\
\text { \% }\end{array}$ \\
\hline $\begin{array}{l}\text { Chảy máu sau } \\
\text { phấu thuât }\end{array}$ & $(I I-4)()$ & 0,2 \\
\hline $\begin{array}{l}\text { Nhiêm trùng chân } \\
\text { trocart }\end{array}$ & 4 & 0,9 \\
\hline \multirow{2}{*}{$\begin{array}{c}\text { Áp xe tồn dư } \\
\text { Tống }\end{array}$} & 3 & 0,6 \\
\hline & \begin{tabular}{|r|r|} 
& 8 \\
\end{tabular} & \begin{tabular}{l|l} 
& 1,7 \\
\end{tabular} \\
\hline \multicolumn{3}{|c|}{ Bảng 9. Thời gian nằm viện sau mố } \\
\hline $\begin{array}{l}\text { Thời gian } \\
\text { (ngày) }\end{array}$ & $\begin{array}{c}\text { Số bệnh nhân } \\
(n=457)\end{array}$ & Tỷ lệ \% \\
\hline 3-5 ngày & 70 & 15,3 \\
\hline 6-7 ngày & 226 & 49,5 \\
\hline$>7$ ngày & 161 & 35,2 \\
\hline Tống & \begin{tabular}{l|l}
457 \\
\end{tabular} & 100.0 \\
\hline Trung bình & $7,13 \pm 1,82$ & $4-19)$ \\
\hline
\end{tabular}

\section{BÀN LUẬN}

4.1. Lý do chuyển mổ mở. Có $11(2,4 \%)$ bệnh nhân PTNS thất bại phải chuyển mổ mở, trong đó:

- 1 BN tổn thương ruôtt trong mổ: sau khi vào ổ bụng phát hiện RT chui trong thanh mạc manh tràng khó bóc tách $R T$, sau khi bóc tách phát hiện tổn thương ruột trong mổ không có khả năng cầm máu và xử lý phải chuyển mổ mở.

- 1 BN không khâu buộc được gốc RT: khi vào ổ bụng phát hiện RT quặt ngược sau manh tràng sát vào thành bụng bên, manh tràng viêm dày đỏ, tiến hành bóc tách quanh quai hồi tràng dính vào $\mathrm{RT}, \mathrm{RT}$ dính sát vào manh tràng được hồi tràng bao quanh; RT hoại tử thủng gốc RT còn tuy nhiên RT rất khó bộc lộ và đã võ nên khó khăn trong khâu buộc phải chuyển mổ mở.

- 2 BN có khả năng cắt được RT qua nội soi nhưng không có khả năng làm sạch ổ bụng:1 $\mathrm{BN}$ khi mổ nội soi ban đâuu không tìm được RT sau khi hút sạch dịch ổ bụng phát hiện RT ở vị trí khó chuyển mổ mở; 1 BN đưa camera vào phát hiện nhiêuu dịch đục giả mạc khắp ổ bụng giữa các quai ruột, mạc treo ruột giả mạc nhiều Douglas đóng thành bánh, RT nằm ở HCP viêm hoại tử thủng ở thân được giả mạc, mạc nối quai ruột bao lại, cắt RT được qua PTNS nhưng không có khả năng làm sạch ổ bụng.

- 1 BN bóc tách RT khỏi mạc treo khó khăn: khi mổ nội soi phát hiện ổ bụng nhiều giả mạc trắng, gốc RT hoại tử để lộ sỏi phân, bóc tách RT khỏi mạc treo khó khăn phải chuyển mổ mở.

- 6 BN không có khả năng xử trí: 1 BN khi đưa camera vào phát hiện ổ bụng nhiều dịch mủ và giả mạc không có khả năng xử trí nội soi; 1 BN khi vào ổ bụng có dịch tiết, HCP có khối áp xe RT do các quai ruột bao lại dính chặt vào ổ bụng không xử trí nội soi được; 1 BN khi vào ổ bụng phát hiện nhiều dịch và giả mạc trong ổ bụng, RT viêm hoại tử hoàn toàn trong có nhiều sỏi phân, tạo ổ áp xe ở HCP và dọc hành lang đại tràng phải các quai ruột non xung huyết phá ố áp xe hút ra nhiều dịch mủ; $1 \mathrm{BN}$ khi vào phát hiện khối áp xe $\mathrm{HCP}$, ổ bụng nhiều dịch mủ và giả mạc, tiến hành phẫu tích khối áp xe nhiều dịch mủ chảy ra, trong khối áp xe có nhiều tổ chức hoại tử khó xác định ranh giới giữa các quai ruột phải chuyển mổ mở; $1 \mathrm{BN}$ khi vào ổ bụng thấy vùng $\mathrm{HCP}$ có khối viêm mủ RT hoại tử sát gốc dính nhiều dễ chảy máu khi phẫu tích phải chuyển mổ mở; 1 BN khi đưa camera vào ổ bụng có nhiều dịch đục, giả mạc giữa các quai ruột douglas trên và dưới gan, RT nằm ở $\mathrm{HCP}$ viêm hoại tử thủng ở đầu, mạc nối và giả mạc tới bao lại không có khả năng PTNS.

Việc chuyển mổ mở vì đảm bảo an toàn cho bệnh nhân và không kéo dài cuộc mổ. Trong trường hợp đánh giá thấy tổn thương phức tạp có nhiều nguy cơ và không chắc chắn PTNS an toàn thì phẩu thuật viên không nên e ngại và lo sợ việc chuyển mổ mở được coi như thất bai PTNS mà nên nhanh chóng quyết định chuyển mổ mở để đảm bảo an toàn cho $B N$.

Nghiên cứu của Kathouda (2005) có tỉ lệ chuyển mổ mở là $8 \%$ do: thành bụng dính không thể bơm hơi PM được, do cấu trúc giải phẫu bất thường hoặc gặp khó khăn khi phẫu tích [1].

Tác giả Yagmurlu (2006) có tỉ lệ chuyển mổ mở là 2,7\% trong đó có 3 bệnh nhân chuyển mổ mở là do PTNS được chỉ định để chẩn đoán xác định ruột thửa thủng trước khi chuyển mổ mở cắt RT [2].

Tóm lại đa số các tác giả đều ghi nhận nguyên nhân chính phải chuyển đổi kỹ thuật là 
do viêm dính nhiều không xác định được mốc giải phẫu, chảy máu. Tổn thương tạng hay do VPM lan tỏa làm cản trở phẫu thuật hoặc do phẫu thuật viên chưa có đủ kinh nghiệm để xử lý. Mặt khác việc chỉ định PTNS trong VPMRT cũng nên được cân nhắc kĩ đặc biệt trong trường hợp chẩn đoán hình ảnh cho thấy tổn thương phức tạp và kinh nghiệm của phẫu thuật viên.

4.2. Chẩn đoán trong PTNS VPMRT. Trong nghiên cứu của chúng tôi viêm phúc mạc toàn thể chiếm tỉ lệ cao nhất $76,7 \%$; tỉ lệ viêm phúc mac khu trú là 21,8\%; tỉ lê áp xe RT là 1,5\%.

4.2.1. Vị trí đăt trocar. Sự thành công của PTNS cũng có góp phần của việc chọn vị trí chuẩn xác đặt trocar và điều này còn phụ thuộc vào thói quen cũng như kinh nghiệm của PTV. Nguyên tắc của PTNS là sự hoạt động đối xứng qua một điểm đó là lỗ trocar ở thành bụng. Khi đưa dụng cư nôi soi song song với kính soi thì cho hình ảnh xuôi, nếu đưa dụng cụ đối diện với ống soi thì cho hình ảnh đối gương rất khó thực hiện nếu không thông thạo. Nghiên cứu của chúng tôi hầu hết các bệnh nhân được đă̆t 3 trocar chiếm 99,1\%; tỉ lẹ bệnh nhân được đặt 4 trocar là $0,9 \%$. Hầu hết các bệnh nhân được đă̆t Trocar tại vị trí Rốn + MSP + HCT chiếm 43,5\%; Ha vị + HCT + Rốn chiếm 20,1\%; Rốn + MSP + Hạ vị chiếm 17,9\%; HCT + Rốn + HCP chiếm 17,3\%; Thượng vị + Rốn + MSP + HCT hoặc HCP + Ha vị + HCT + Rốn chiếm 0,4\%; Rốn + HCP + Ha vị chiếm $0,2 \%$.Nghiên cứu của chúng tôi cho kết quả tương đương với tác giả Agresta (2012) [3].

Chúng tôi hầu hết đặt 3 trocar trong khi có 4 ca phải đặt thêm trocar. Hầu hết các tác giả cho rằng chỉ cần 3 trocar là đủ để thao tác kĩ thuật và kết quả PTNS vẫn đảm bảo. Theo chúng tồi số trocar nên đă̆t ít nhất là 3 để đảm bảo thao tác đúng kỹ thuật và an toàn cho bệnh nhân và nếu có khó khăn thì nên đặt thêm trocar.

4.2.2. Bơm hớ ổ bung. Chúng tôi áp dụng kĩ thuât rach da lỗ nhỏ dưới rốn, đặt trocar trực tiếp để bớm hơi khoang $P M$, đa số các bệnh nhân được bơm hơi ổ bụng ở mức áp lực 11-12 $\mathrm{mmHg}$ chiếm $72,0 \%$; tỉ iệ bệnh nhân được bơm ở mức áp lực 8-10 mmHg là 28,0\%; và không có bệnh nhân nào được bơm hơi ổ bụng ở mức áp lực $>12 \mathrm{mmHg}$. Tác giả Agresta (2012) cho rằng mặc dù kĩ thuật bơm hơi phúc mạc bằng kim Veress được nhiều tác giả áp dung nhưng có nhiều nguy cơ gây biến chứng nên tác giả đã dùng kĩ thuât đăt trocar trực tiếp sau khi đã rach da một đường nhỏ, kết quả rất khả quan hầu như không gây tai biến [3].
4.2.3. Kĩ thuật cắt gốc RT. Trong nghiên cứu của chúng tôi kĩ thuật cắt RT xuôi dòng chiếm đa số trường hợp 96,9\%; chỉ có $3,1 \%$ bệnh nhân được cắt gốc RT ngược dòng.

4.2.4. Thời gian phẫu thuật nội soi. Trong nghiên cứu của chúng tôi Thời gian phẫu thuật trung bình là 50,35 $\pm 17,87$ (nhanh nhất 17 phút và chậm nhất là 155). Tỉ lệ bênh nhân có thời gian phẫu thuật chiếm 30-60 phút cao nhất chiếm $64,8 \%$; thời gian phẫu thuật từ $61-90$ phút chiếm 18,6\%; thời gian phẫu thuật $\leq 30$ phút chiếm 14,4\%; từ 91-120 phút chiếm 2,0\%; $>120$ phút chiếm $0,2 \%$. Trong đó thời gian phẫu thuật trung bình của các trường hợp phải chuyển phẫu thuật mở là 107,91 \pm 25,77 nhanh nhất là 60 phút chậm nhất là 145 phút. Kết quả của chúng tôi cũng chỉ ra thời gian mổ càng dài thì nguy cơ chuyển mổ mở càng cao. Ngoài ra thời gian mổ dài gây các biến cố bất lợi về gây mê của bệnh nhân và thời gian hồi phục sau mổ. Tác giả Cueto (2006) công bố thời gian PTNS VPMRT trung bình là 62 phút (32-132 phút) [4]. Fukami thực hiện 34 ca PTNS VPMRT ghi nhận thời gian mổ trung bình là $97,9 \pm 30,6$ phút [5].

Tóm lại các tác giả công bố thời gian PTNS cũng như mổ mở VPMRT rất khác nhau phụ thuộc vào kinh nghiệm của PTV, tình trạng VPMRT, cách giải quyết súc rửa ổ bụng, cắt RT,...Chúng tôi quan sát thây thời gian phẫu thuật phụ thuộc rất nhiều vào thời gian súc rửa ổ bụng mà thời gian này lại tùy thuộc vào các yếu tố khác như: tình trạng ổ bụng bẩn hay sạch, ruôt chướng nhiều hay ít, có nhiều giả mạc không, bệnh nhân béo hay gầy. Những ca mổ phức tạp kéo dài thường có nhiều yếu tố không thuân Iợi ngay từ khi bắt đầu cuộc mổ nên cần phải dự đoán trước mổ để tránh phải chuyển mổ mở. Những trường hợp $\mathrm{BN}$ đến muộn, bụng chướng căng, mất nhu động ruột thì nên cân nhắc mổ mở ngay từ đầu để tránh phải chuyển đổi từ PTNS sang mổ mở.

4.2.5. Tai biến trong phẫu thuật. Nhiều tác giả công bố tỉ lệ tai biến trong PTNS thấp hơn so với mổ mở tuy vậy các khuyến cáo gần đây chỉ ra mỗi một thao tác trong PTNS đều có thể gặp phải những tai biến và biến chứng. Nhiều nghiên cứu đã đưa ra kết luận PTNS sẽ có thể là tiêu chuẩn vàng thay thế cho mổ mở kinh điển trong xử trí VPMRT.

Nghiên cứu của chúng tôi, trong quá trình mổ có 1 bệnh nhân gặp tai biến chảy máu sau mổ tại vị trí chọc Trocar trên rốn và 1 bệnh nhân có tổn thương ruột non. Tác giả Kathouda (2005) công bố tỉ lệ biến chứng TPNS VPMRT trên 247 
BN là 18,5\% [1]. Chúng tôi gặp 1 trường hợp chảy máu sau mổ tại vị trí chọc trocar trên rốn và được xử lý cầm máu tích cực sau đó bệnh nhân ổn định. Trường hợp tổn thương ruột non được chuyển mổ mở để xữ trí tổn thương.

Tác giả Katkhouda (2005) công bố tai biến tổn thương bó mạch thượng vị rất nguyhiểm phải mổ mở giải quyết tổn thương. Tai biến này có thể giảm thiểu được bằng cách quan sát trực tiếp thành bụng phía ngoài động mạch thượng vị và sử dụng các loại trocar mới không quá nhọn. Trước khi rút trocar cũng nên quan sát lại khoang PM để phát hiện các trường hợp chảy máu tữ thành bunng. Biến chứng rò qua lỗ trocar ở ngày hậu phấu đầu tiên do tổn thương bỏng điện ở bờ tự do của đoạn cuối hồi tràng, tổn thương này không phát hiện được trong lúc mổ, BN được mổ cắt manh tràng do đó tác giả khuyến cáo hạn chế dùng dao điện đơn cực ở những trường hợp RT khó cắt, đặc biệt ở BN béo phì hoặc khả năng quan sát phẫu trường hạn chế. Tác giả cũng đưa ra nhận xét tổn thương mạch máu và các tạng do chọc trocar thường là những tai biến rất nặng do: 1 , tổn thương gặp phải khi bơm hơi khoang PM không đủ căng hoặc chọc kim bơm hơi với tư thế BN xấu; 2, Trocar đầy vào quá xa do PTV cầm không chắc hoặc rạch da quá nhỏ làm da trượt đi khi đâm do đó nên cầm chắc trocar trong tay và một tay đẩy trocar một tay giữ thành bụng; 3, Đặt trocar xa các sẹo mổ cũ để tránh các quai ruột dính vào vết mổ cũ [1].

4.3. Thời gian nằm viện sau mổ. Trong nghiên cứu của chúng tôi thời gian nằm viện sau phẫu thuật trung bình là $7,13 \pm 1,82$ (4-19) trong đó thời gian nằm viện sau phẫu thuật là 67 ngày chiếm tỉ lệ cao nhất 49,5\%; thời gian nằm viện sau phẫu thuật > 7ngày chiếm $35,2 \%$; thời gian nằm viện sau phẫu thuật 3-5 ngày là $15,3 \%$. BN nằm viên dài ngày thường do tình trạng nhiễm khuẩn vết mổ và áp xe tồn dư phải điều trị kháng sinh dài ngày.

Tác giả Long K. H. (2001) công bố thời gian BN có nhu động ruột trở lại là 5,1 ngày; thời gian nằm viện trung bình là 6 ngày, khôi phục hoạt động bình thường là 17 ngày [7].

Tác giả Katsuno G. (2008) công bố thời gian nằm viện trung bình là $8,9 \pm 3,7$ ngày [8].

PTNS là một phẫu thuật ít xâm nhập có thời gian hồi phục nhanh, các BN nhanh chóng hồi phục và làm việc bình thường. Thời gian nằm viện sau mổ PTNS VPMRT cũng tương đối ngắn đầy là ưu điểm nổi bật của PTNS trong điều trị VPMRT. Ngoài ra PTNŚ ít gây sang chấn và giảm nguy cơ dính ruột sau mổ so với mổ mở do hạn chế quá trình tiêu sợi huyết tại chỗ của PM giúp giảm quá trình dính sẹo mổ gây ra sau những sang chấn PT. Tuy nhiên PTNS cũng có những nhược điểm nhất định là giá thành cao và cân phải có nhiều trang thiết bị phòng mổ và PTNS cũng được coi là nguy hiểm với các trường hợp VPM do có nguy cơ cao nhiễm khuẩn huyết và tắc mạch do các mạch máu bị cương tụ do VPM. Nhiêu nghiên cứu cũ̃ng chỉ ra tăng áp lực ổ bụng do bơm hơi không gây ảnh hưởng gì. Bơm hơi PM không làm tăng sự phát tán nhiếm trùng với điều kiện bơm hơi với áp lực thấp và kết hợp dùng kháng sinh 18. Đa số các nghiên cứu ghi nhận ưu điểm nổi bật của PTNS về thời gian đau sau mổ, cường độ đau sau mổ, thời gian nằm viện sau mổ.

4.4. Biến chứng sau mổ. Trong nghiên cứu của chúng tôi tỉ lệ biến chứng sớm sau mổ là $1,7 \%$ trong đó có $0,9 \%$ nhiễm trùng chân Trocar; $0,6 \%$ bệnh nhân có áp xe tồn dư; $0,2 \%$ có chảy máu sau mổ.

Có 4 trường hợp nhiễm trùng chân trocar được điều trị bằng vệ sinh thay băng tại chỗ và kết hợp dùng kháng sinh. Với 3 trường hợp có áp xe tồn dư sau mổ chúng tôi điêu trị kháng sinh tích cực kết hợp với chọc hút mủ không mổ lại, nguyên nhân nhiều khả năng là do súc rửa ổ bụng chưa sạch hoặc hút chưa hết dịch rửa. Chúng tôi cũng gặp 1 trường hợp chảy máu sau mổ phải điêu trị cầm máu tích cực và truyền bù khối lượng tuần hoàn sau đó bệnh nhân ổn định. Đối với biến chứng muộn sau mổ chúng tôi gặp $1(0,2 \%)$ trường hợp tắc ruột sau mổ. Chúng tôi không gặp trường hợp nào tử vong sau mổ VPMRT.

Nhiểm khuẩn lố trocar liên quan nhiều tới động tác lấy RT qua lỗ trocar và tình trạng tổn thương của RT. Do đó với những túi đựng RT tự tạo giá cả phù hợp với điều kiện Việt Nam thì theo chúng tôi tî lệ nhiễm khuẩn này là chấp nhận được.

Nhiễm khuẩn vết mổ và áp xe khoang phúc mạc là biến chứng hay gặp. Trong đó nhiễm khuẩn vết mổ ít khi gây tử vong hay biến chứng nghiêm trọng nhưng gây khó chịu cho BN ảnh hưởng tới thời gian hồi phục, còn áp xe khoang phúc mạc là biến chứng nguy hiểm có khả năng gây tử vong.

Tác giả Katkhouda (2005) công bố có thể giảm tỉ lệ nhiếm khuẩn ở vùng tiểu khung nếu đại tràng Sigma được vén lền, $\mathrm{Bn}$ ở tư thế Trendelenburg, tiểu khung được súc rửa và hút cẩn thận. Tỉ lệ áp xe khoang PM sau PTNS cắt RT tương đối cao cần phải lưu ý đặc biệt khi 
VPMRT. Do đó một số tác giả chủ trương mổ mở trong VPMRT. Rách bao đựng RT cũng là một nguyên nhân gây nhiễm trùng vết mổ [1].

Như vậy nghiên cứu của chúng tôi cho thấy PTNS VPMRT tai các tỉnh miền núi phía Bắc khá an toàn với tỉ lệ biến chứng sớm là $1,7 \%$. Điều này cho thấy PTNS là một lựa chọn hợp lý trong điều trị VPMRT khi các PTV đã có kinh nghiệm và trang thiết bị đầy đủ tỉ lệ biến chứng rất thấp.

\section{KẾT LUÂ̂N}

Phẫu thuật nội soi viêm phúc mạc ruột thừa được ứng dụng tại các Bệnh viện đả khoa tỉnh miền núi phía Bắc cho thấy tính khả thi, hiệu quả, độ an toàn cao và tỉ lệ thành công lớn. Như vậy phẫu thuật nội soi trong điều trị viêm phúc mạc ruột thừa có thể được ứng dụng rộng rãi trong lâm sàng để giảm thiểu biến chứng và giúp bệnh nhân nhanh chóng bình phục.

\section{TÀI LIẸU THAM KHẢO}

1. Namir Katkhouda (2005), "Laparoscopic Versus Open Appendectomy A Prospective Randomized
Double-Blind Study", Annals of Surgery, pp. 135-145.

2. A. Yagmurlu (2006), "Laparoscopic appendectomy for perforated appendicitis: a comparison with open appendectomy", Surg Endosc., pp. 1051-1054.

3. F. Agresta (2004), "Direct trocar insertion vs veress needle in nonobese patients undergoing laparoscopic procedures: A randomized prospective single-center study", Surg Endosc., pp. 1778-1781.

4. Cueto J, D' Allemagne $B$, and Varquer - Frias JA, Et al (2006), "Morbidity of laparosopic surgery for complicated appendicitis: an inter national Study", Surg. Endosc. , pp. 717 - 720.

5. Yasuyuki Fukami (2007), "Value of Laparoscopic Appendectomy in Perforated Appendicitis", World J Surg., pp. 93-97.

6. CM Pring (2007), "Aortic injury using the Hasson trocar: a case report and review of the literature", Ann R Coll Surg Engl, pp. 89-91.

7. Kirsten Hall Long (2001), "A prospective randomized comparison of laparoscopic appendectomy with open appendectomy: Clinical and economic analyses", Surgery, pp. 390-400.

8. Goutaro Katsuno (2008), "Laparoscopic Appendectomy for Complicated Appendicitis: A Comparison with Open Appendectomy", World J Surg., pp. 208-214.

\section{NGHIÊN CỨU ĐĂC ĐIỂM LÂM SÀNG VÀ KẾT QUẢ ĐIỀU TRI VẾT LOÉT CỦA LASER HE-NE TẠI BỆNH VIỆN DA LIỄU THÀNH PHỐ CẦN THO' NĂM 2020}

\section{TÓM TẮT.}

Mục tiêu: Mô tả đặc điểm lâm sàng và đánh giá kết quả của laser He-Nie trong điều trị vết loét. Đối tượngvà phương pháp: Nghiên cứu mô tả có phân tích 30 bệnh nhân có vết loét điều trị bằng laser $\mathrm{He}$ Ne tai BV Da liê̂u TPCTnăm 2020. Kết quả: nhóm 4060 tuổi chiếm tỉ lệ cao nhất (56,7\%). 100\% bệnh nhân có đau nhứć, $46,7 \%$ sốt, $36,7 \%$ châm chích. Trước điều trị, điểm đau trung bình 3,2; kích thước trung bình 17,5mm; đô sâu trung bình $1 \mathrm{~mm}$; rì dich (93,3\%);mủ (10\%), viểm đỏ $(80 \%)$. Sau 72 giờ điều trị, điểm đau trung bình là 1,4; kích thước trung bình là 12,5mm; độ sâu trung bình là $0 \mathrm{~mm}$; rì dịch (30\%);mủ $(3,3 \%)$; viêm đỏ $(83,3 \%)$.Sau 72 giờ điêu trị, 56,7\% bệnh nhân giảm 25\% kích thước vết loét. Kết luâan: Sự giảm kích thước và độ sâu vết loét được ghi nhận từ 48 giờ sau điêu trị. Laser $\mathrm{He}-\mathrm{Ne}$ hằng ngày đển khi vết loét lành hoàn toàn hoặc tối thiểu 3 ngày được khuyến cáo điều trị.

*Trường Đại học Y Dước Cần Tho

Chịu trách nhiệm chính: Huỳnh Văn Bá

Email: bs.ba_fob@yahoo.com.vn

Ngày nhận bài: $13 / 6 / 2021$

Ngày phản biên khoa họ: 22/7/2021

Ngày duyệt băi: 25/8/2021

\author{
Dương Lê Hồng Thảo*, Trần Gia Hưng*, \\ Huỳnh Văn Bá*, Nguyễn Thị Thùy Trang* \\ Tư khóa: Laser He-Ne, vết loét, loét da mãn tính. \\ SUMMARY \\ DESCRIBE THE CLINICAL FEATURES AND \\ EVALUATE THE RESULTS OF HELIUM-NEON \\ LASER IN ULCER TREATMENT \\ Objective: Describe the clinical features and
} evaluate the results of Helium-Neon laser in ulcer treatment. Subjects and methods: Descriptive studies with analysis 30 patients were treated by Helium-Neon laser at Can Tho Hospital of DermatoVenereology in 2020. Results: $40-60$ years old people have the highest rate $(56,7 \%) .100 \%$ patients have experienced pain symptom; $46,7 \%$ fever. Before treatment, average VAS (Visual analog scales was 3,2; average size was $17,5 \mathrm{~mm}$; average depth was $1 \mathrm{~mm}$; ooze $(93,3 \%)$; pus $(10 \%)$, inflammation $(80 \%)$. After 72 hours of treatment, average VAS is 1.4; average size is $12,5 \mathrm{~mm}$; average depth is $0 \mathrm{~mm}$; ooze $(30 \%)$; pus $(3,3 \%)$, inflammation $(83,3 \%)$. After 72 hours of treatment, $56,7 \%$ of the patients have reduced $25 \%$ the size of the ulcers. Conclusion: A decrease in the size and depth of the ulcer was observed 48 hours after treatment. Helium-Neon laser daily until the lession is completely healed or for at least 3 days is recommended for treatment. 